\title{
Wastewater Remediation Using Microbial Fuel Cells and Bioenergy Production
}

\section{Balaji B. Prasath, Karen Poon*}

Program of Food Science and Technology, Division of Science and Technology, BNU-HKBU United International College, 28 Jinfeng Road, Tangjiawan, Zhuhai, Guangdong, P.R. China

Corresponding author: Karen Poon: karenpoon@uic.edu.hk

Program of Food Science and Technology, Division of Science and Technology, BNU-HKBU United International College, 28 Jinfeng Road, Tangjiawan, Zhuhai, Guangdong, P.R. China

Fax: (86) 756-3620882

Tel: (86) 756-3620621 


\begin{abstract}
.
Microbial Fuel Cells (MFCs) representing a promising technology for the extract of energy and resources through wastewater and it also offer an economic solution to the problem of environment effluent and energy crisis in near future. The advance device is rather appealing, due its potential benefits, its practical application is, however hindered by several drawbacks, such an internally competing microbial reaction, and low power generation. This report is an endeavor to address various design connected to the MFCs application to wastewater treatment, in particular cost effective bioelectricity from waste water are reviewed and discussed with a multidisciplinary approach. The conclusions drawn herein can be of practical interest to all new researchers dealing with effluent wastewater treatment using MFCs.
\end{abstract}

Key words: wastewater treatment; microbial fuel cells; bioenergy

\title{
Background
}

Microbial fuel cells (MFC) technology is a rapidly evolving and an emerging technology in recent years and has attracted a lot of attention from researchers in the fields of wastewater treatment and bioenergy production (Logan and Rabaey, 2012; Malvankar and Lovley, 2012). These promising biotechnologies are capable of bio electrochemical systems that convert energy contained in organic matter substrates in wastewaters (e.g. municipal wastewater, food, industrial, landfill leachates, swine wastewater and urine into electrical energy (kan et al., 2011; Kiely et al., 2011a; Santoro et al., 2011 and Sharma et al., 2011). A typical MFC is consisting of two chambers, i.e. the anaerobic anode chamber and the aerobic cathode. The two chambers are separated by a membrane (e.g., proton exchange membrane) where protons and other ions are transferred from the anode chamber to the cathode chamber, while electrons from the anode chamber are transferred to the cathode chamber through an external electrical circuit and a resistor for electricity production (Li et al., 2010). MFCs have been initially developed as a method for simultaneous wastewater treatment and electricity production. While interesting, many researchers are realizing that the economic and environmental value of electricity from MFC cannot compete for that of other energy sources at this stage. Therefore, a development has been initiated recently that the researchers have even 
invented a new method expands the scope of MFCs from electricity production to an increasing number of other specialized applications and reduce its costs so that it can produce substantial amounts of electricity, in addition to treating wastewater, and be costeffective for industries. Many research attempted to understand MFCs, their structure based biosensor, and applications, for example microbial desalination cell (MDC) and microbial electrolysis cell (MEC), which can be applied in different environments for monitoring of organic matter, microbial activity, reduce the salinity of brackish water or seawater and rich chemicals production (e.g., hydrogen, methane, $\mathrm{H}_{2} \mathrm{O}_{2}$ ) from carbohydrate-rich wastes (Jiang et al., 2017; Chouler et al., 2015; Lian et al., 2017; Chen et al., 2015; Chen et al., 2016; El Mekawy et al., 2014; Sevda et al., 2015).

MFCs reaction:

In a fuel cell, a very simple reaction occurs; microbes oxidize pollutants substrates such as nitrates, phosphates, other nutrient products and metals in the wastewater under anaerobic conditions which is able to produce clean and direct electricity production in MFCs is the result of oxidation-reduction reactions (Behera and Ghangrekar, 2009; Hamelers et al., 2010). That result in electron release, transfer and acceptance through electrochemical reactions at the electrodes in the anode and cathode chambers. These electrons were generated via anaerobic respiration by microorganisms in the anode chamber then the flow of electrons from the anode to the cathode is driven by the voltage difference between the two electrodes and the concentrations of readily available electron donors and acceptors at the anode and cathode surfaces, respectively.

$$
\text { pollutant }+\mathrm{H}_{2} \mathrm{O} \rightarrow \mathrm{CO}_{2}+\mathrm{NH}^{+}{ }_{4}+\mathrm{HCO}_{3}^{-}+\mathrm{H}^{+}+\mathrm{e}^{-}(1.1)
$$

The bacteria in the anolyte or at the anode surface carry out this reaction. Liberated electrons travel through the anode to the cathode via the electrical circuit where they react with the electron acceptors at the cathode, as described by Equation 1.2:

$$
\mathrm{QA}+\mathrm{e}-\rightarrow \mathrm{QA}^{-}(1.2)
$$

Where, $\mathrm{QA}=$ oxidized electron acceptor, $\mathrm{QA}^{-}=$reduced electron acceptor.

. The following oxidation-reduction reactions represent possible bioelectro-chemical reactions in microbial fuel cells generating electricity utilizing wastewater as a substrate and other pollutants such as nitrates, phosphates, and others as electron acceptors The typical reactions in the anode and cathode of MFCs were described below 
Electron donor/acceptor Reactions in Anode

$$
\begin{aligned}
& \mathrm{C}_{2} \mathrm{H}_{3} \mathrm{O}_{2}{ }^{-}+4 \mathrm{H}_{2} \mathrm{O} \rightarrow 2 \mathrm{HCO}_{3}-+9 \mathrm{H}++8 \mathrm{e} \\
& \text { Glucose }-\mathrm{C}_{6} \mathrm{H}_{12} \mathrm{O}_{6}+\mathrm{H}_{2} \mathrm{O} \rightarrow 6 \mathrm{CO}_{2}+24 \mathrm{e}+24 \mathrm{H}+ \\
& \text { Butyrate }-\mathrm{C}_{4} \mathrm{H}_{8} \mathrm{O}_{2}+2 \mathrm{H}_{2} \mathrm{O} \rightarrow 2 \mathrm{C}_{2} \mathrm{H}_{4} \mathrm{O}_{2}+4 \mathrm{H}++4 \mathrm{e}^{-} \\
& \text {Glycerol }-\mathrm{C}_{3} \mathrm{H}_{8} \mathrm{O}_{3}+6 \mathrm{H}_{2} \mathrm{O} \rightarrow 3 \mathrm{HCO}_{3}-+17 \mathrm{H}++14 \mathrm{e}^{-} \\
& \text {Malate }-\mathrm{C}_{4} \mathrm{H}_{5} \mathrm{O}_{5}^{-}+7 \mathrm{H}_{2} \mathrm{O} \rightarrow 4 \mathrm{H}_{2} \mathrm{CO}_{3}+11 \mathrm{H}++12 \mathrm{e}^{-} \\
& \text {Citrate - } \mathrm{C}_{6} \mathrm{H}_{5} \mathrm{O}_{7}{ }^{3-}+11 \mathrm{H}_{2} \mathrm{O} \rightarrow 6 \mathrm{H}_{2} \mathrm{CO}_{3}+15 \mathrm{H}++18 \mathrm{e}^{-} \\
& \text {Sulfur - HS- } \rightarrow \mathrm{S}^{0}+\mathrm{H}++2 \mathrm{e}^{-}
\end{aligned}
$$

Electron donor/acceptor Reactions in Cathode -

$$
\begin{aligned}
& \text { Oxygen }-\mathrm{O}_{2}+4 \mathrm{e}+4 \mathrm{H}+\rightarrow 2 \mathrm{H}_{2} \mathrm{O} \\
& \text { Bicarbonate }-\mathrm{HCO}_{3}-+9 \mathrm{H}++8 \mathrm{e}-\rightarrow \mathrm{CH}_{4}+3 \mathrm{H}_{2} \mathrm{O} \\
& \text { Acetate }-\mathrm{C}_{2} \mathrm{H}_{3} \mathrm{O}_{2}-+5 \mathrm{H}++4 \mathrm{e}-\rightarrow \mathrm{C}_{2} \mathrm{H}_{6} \mathrm{O}+\mathrm{H}_{2} \mathrm{O} \\
& \text { Nitrate }-2 \mathrm{NO}_{3}-+12 \mathrm{H}++10 \mathrm{e}-\rightarrow \mathrm{N}_{2}+6 \mathrm{H}_{2} \mathrm{O} \\
& \text { Nitrite - } \mathrm{NO}_{2}-+2 \mathrm{e}+2 \mathrm{H}+\rightarrow \mathrm{N}_{2}+\mathrm{H}_{2} \mathrm{O} \\
& \text { Permanganate }-\mathrm{MnO}_{4}-+4 \mathrm{H}++3 \mathrm{e}-\rightarrow \mathrm{MnO}_{2}+2 \mathrm{H}_{2} \mathrm{O} \\
& \text { Manganese dioxide }-\mathrm{MnO}_{2}+\mathrm{H}++\mathrm{e}-\rightarrow \mathrm{MnOOH}_{(\mathrm{S})} \\
& \text { Iron - Fe }{ }_{3}++\mathrm{e}-\rightarrow \mathrm{Fe}_{2}+ \\
& \text { Copper }(\mathrm{II})-4 \mathrm{Cu}_{2}++8 \mathrm{e}-\rightarrow 4 \mathrm{Cu}(\mathrm{s})
\end{aligned}
$$

In this section of the review, we are mainly focused on the substrates for pollutant reduction with the help of MFC. The environmental and financial impacts of microbial fuel cell wastewater treatment systems could potentially be very significant, especially with a worsening energy crisis causing us to look more and more to alternative sources of electricity and summarizes almost all the relevant literature available in the field of MFC research till date. It also provides a better understanding of the processes that occur within these MFCs is thus very important to the sustainable energy and insight into the difficulties, challenges and future of this technology there by encouraging more research efforts towards commercialization of the technology.

\section{Pollutant Removal by MFCs}


The pollution of wastewater effluents has gained worldwide attention due to their toxicity, difficult disposal, and accumulation in the living organisms. Therefore, treatment of wastewater is an important environmental issue. Several methods have been developed to treat wastewater, including ion exchange, chemical precipitation, electrolysis, and reverse osmosis. However, most of these methods required high operational and maintenance costs, and generated toxic sludge. Therefore, treating wastes with MFC would be an innovative method to reduce waste and harvest power at the same time (Zhang et al., 2015 and Mateo-Sagasta et al., 2014). The organic components in some wastewaters plus microbial biomass generated in the activated sludge process can be used as substrate or feedstock to an MFC, acting as a resource and not simply a waste. This approach can be considered a partial solution for wastewater treatment, or an integrated part of a larger waste treatment system. The benefit of the MFC is that the electricity it produces can offset some of the energy required to run the more conventional wastewater treatment operations. For example, fermented primary sludge from domestic wastewater treatment has been utilized for electricity generation using single-chamber air-cathode MFCs (Yang et al., 2013). An MFC has great potential for treating various wastewater sources like municipal agricultural, industrial, dairy and brewery/ food. For Example, Anode chamber fed with containing azo dyes for decolorization, and simultaneous production of electricity with the help of microorganisms as biocatalysts. Microbial fuel cell for treatment of azo dye Acid Orange 7 coloured removed 73.7 and $80.6 \%$ and voltage density $38 \mathrm{~mW} / \mathrm{m} 2$ and $167.4 \mathrm{Mv}$ (Fernando et al., 2012 and Thung et al., 2015) and Reactive Blue 221 dye decolourisation using dual chamber microbial fuel $84 \%$ coloured removed and voltage density as 28 $\mathrm{mW} / \mathrm{m} 2$ (Bakhshian et al., 2011). Alizarin yellow $\mathrm{R}$ azo dye decolorization using Anaerobic baffled reactor coupled with biocatalyzed electrolysis system (ABR-BES) colored removed $96.4 \%$ and voltage density as $24.1 \mathrm{~A} / \mathrm{m} 3$ (Cui et al.,2014). Congo red azo dye decolorisation using air-cathode single-chamber microbial fuel cell $90 \%$ colored removed and voltage density as $192 \mathrm{~mW} / \mathrm{m} 2$ (Hou et al., 2011). Another abundant waste product worldwide is human waste urine/ Feces is which requires energy intensive treatment processes in modern wastewater treatment plants. Thus, urine/ Feces could be used to revolutionize the way we produce bioelectricity by harnessing the potential power 
of the waste using MFCs. In 2011, Fangzhou et al., 2011 demonstrated the feasibility of using human feces as a substrate using dual chamber microbial fuel $71 \%$ pollutant removed and voltage density as $70.8 \mathrm{~mW} / \mathrm{m}^{2}$. Santoro et al., 2013 remove pollutant from human urine using Single-chambered microbial fuel cell $75 \%$ and voltage density as 55 mW. In 2010, Cercado-Quezada et al., study the testing various food-industry wastes as the substrate in a dual-chambered in MFC, and produced a maximum electricity production $209 \mathrm{~mA} / \mathrm{m}^{2}$. Li et al., 2013 utilized food waste leachate as substrate in a double-chambered MFC, resulting in 87\% removal of COD and power density of 123.8 $\mathrm{mW} / \mathrm{m}^{2}$. A two-chambered MFC was used with anaerobic sludge as inoculum, with pretreated cheese whey wastewater at different organic loads and removal of COD 94\% and produced maximum power density of $46.00 \mathrm{~mW} / \mathrm{m}^{2}$ (Tremouli et al., 2013). In winery waste water treatment using MFC and pollutant removal $84 \%$ and power density of 890 $\mathrm{mW} / \mathrm{m}^{2}$ (Penteado et al., 2016) and wine wastewater as the substrate in a dual-chambered in MFC power density of $3.8\left(\mathrm{~W} / \mathrm{m}^{3}\right)$ Rengasamy and Berchmans, 2012. Chocolate industry wastewater as the substrate in a dual-chambered in MFC and produced maximum power density $0.302\left(\mathrm{~mA} / \mathrm{cm}^{2}\right)$ Patil et al., 2009. Dairy wastewater in Single chambered microbial fuel cell and produced $25\left(\mathrm{~mA} / \mathrm{m}^{2}\right)$ Velasquez-Orta et al., 2011.

A new-style microalgae MFC has appeared; it has the capacity to convert solar energy into electricity via the metabolism of photosynthetic microorganisms (Lee et al., 2015). The use of membrane-less MFCs based on biocathodes shows a remarkable achievement with a $24 \mathrm{~h}$ hydraulic retention time, in which the rate of the removal of COD and approached 90\% and 99\%, respectively(Zhang et al., 2015). In the future, aerobic biocathodes can utilize inorganic compounds, such as nitrate, sulfate, and iron, in wastewater as terminal electron acceptors (Sharma and Kundu 2010), which provides a new way of degrading inorganic salt. Wastewater effluents are globally generated every year, containing in variable concentrations organic matter, nitrogen (mainly in NH4+ form), phosphorus, inorganic salts and pathogenic microorganisms, all potential contributors to surface water bodies eutrophication and groundwater contamination. Now that you understand how MFC's work, let's take a look at the role they play in the energy industry. The most immediately foreseeable application of an MFC is in wastewater treatment. Microbes love sewage, and the conditions of a 
wastewater treatment plant are ideal for the types of bacteria that can be used in an MFC. Swine wastewater has been used for electricity generation with MFCs as well. Exoelectrogens are more than happy to breakdown and metabolize the carbon rich sewage of a wastewater stream to produce electrons that can stream into a cheap conductive carbon cloth anode. The electricity generated from the MFC also offsets the energy cost of operating the plant. As an added bonus, the bacteria eat a lot of the sludge normally present in wastewater. Due to the characteristics of the MFC, it is considered to be a potential solution to the current global energy and environment crises, but its power output is still relatively low. Research on finding ways to improve performance is needed to elevate MFC technologies from the laboratory to commercialization (Logan, 2012). Different types of applications have already been reported during the last decades. Conversion of wastewater into bioenergy is one type of application of MFC that has been widely documented (Logan \& Rabaey, 2012). Researchers studying in different disciplines are contributing to the development of the MFC. Material scientists and engineers study electrodes and membranes such as the effects of carbon electrode morphology on MFCs (Sanchez et al., 2015). Environmental engineers (Logan, 2008) study the treatment effectiveness of MFCs, and electrical engineers study the energy harvesting processes (Alaraj et al., 2014; Corbella et al., 2015).

Microbial communities involve in some wastewaters treatment by microbial fuel cell.

\begin{tabular}{|c|c|c|c|c|c|}
\hline Microbial community & Design of MFC & Wastewater & Max. power density & $\begin{array}{c}\text { COD removal } \\
(\%)\end{array}$ & Reference \\
\hline E.coli $($ DH5-a) & SCMFC & Dairy & $0.2 \mathrm{~W} / \mathrm{m}^{3}$ & 80 & Ayyaru et al., 2011 \\
\hline Acetobacter aceti & DCMFC & Bad wine & $3.82 \mathrm{~W} / \mathrm{m}^{3}$ & 59 & Rengasamy et al.,2012 \\
\hline Shewanella oneidensis & H-type MFCs & Agriculture & $38 \mathrm{~mW} / \mathrm{m}^{2}$ & 73.7 & Fernando et al., 2012 \\
\hline $\begin{array}{c}\text { Bacteroidetes } \\
\text { thermophiles }\end{array}$ & $\begin{array}{c}\text { Plate-type } \\
\text { mediator-less } \\
\text { MFCs }\end{array}$ & Alcohol distillery & $0.36 \mathrm{~W} / \mathrm{m}^{2}$ & 76 & Ha et al., 2012 \\
\hline $\begin{array}{c}\text { Halanerobium } \\
\text { praevalens }\end{array}$ & SCMFC & $\begin{array}{l}\text { Barnett Shale } \\
\text { formation }\end{array}$ & $47 \mathrm{~mW} / \mathrm{m}^{2}$ & 68 & Monzon et al., 2017 \\
\hline Mixed bacterial & DCMFC & Distillery & $63.8 \mathrm{~mW} / \mathrm{m}^{2}$ & 63 & Samsudeen et al., 2015 \\
\hline Stenotrophomonas sp. & Tubular upflow & seafood processing & $105 \mathrm{~mW} / \mathrm{m}^{2}$ & 95 & Jayashree et al., 2016 \\
\hline
\end{tabular}




\begin{tabular}{|c|c|c|c|c|c|}
\hline & MFCs & & & & \\
\hline $\begin{array}{c}\text { Sphingobacterium and } \\
\text { Bacillus } \mathrm{sp}\end{array}$ & DCMFC & Dairy & $131 \mathrm{~mW} / \mathrm{m}^{2}$ & 76 & $\begin{array}{l}\text { Retnaningrum, } \\
\text { et al., } 2016\end{array}$ \\
\hline Geoalkalibacter & SCMFC & yogurt & $1043 \mathrm{~mW} / \mathrm{m}^{2}$ & 87 & Haiping Luo et al.,2017 \\
\hline Chlorella vulgaris & DCMFC & Industrial Effulent & $327.67 \mathrm{~mW} / \mathrm{m}^{2}$ & 78.6 & $\begin{array}{l}\text { Ronald Huarachi- } \\
\text { Olivera, et al.,2018 }\end{array}$ \\
\hline Scenedesmus acutus & $P M F C$ & Domestic & $400 \mathrm{~mW} / \mathrm{m}^{3}$ & 87 & Angioni, et al.,2018 \\
\hline Blue Green Algae & DCMFC & Synthetic & $78.12 \mathrm{~mW} / \mathrm{m}^{2}$ & 89.23 & Yadav et al.,2014 \\
\hline Mixed microalgae & $\begin{array}{l}\text { Up flow ML- } \\
\text { MFC }\end{array}$ & Domestic & $481 \mathrm{~mW} / \mathrm{m}^{3}$ & 77.9 & Jiang et al.,2013 \\
\hline Chlorella vulgaris & SCMFC & Domestic & $268.5 \mathrm{~mW} / \mathrm{m}^{2}$ & 67 & Hai-ming Jiang 2017 \\
\hline Chlorella vulgaris & SCMFC & Dye textile & $123.2 \mathrm{~mW} / \mathrm{m}^{3}$ & 98 & Logroño et al.,2017 \\
\hline Mixed microalgae & SMFC & aquaculture pond & $22.19 \mathrm{~mW} / \mathrm{m}^{2}$ & 81.6 & Neethu et al.,2017 \\
\hline
\end{tabular}

Single chamber MFC (SCMFC), Dual-chambered MFC (DCMFC), photosynthetic microalgae microbial fuel cells (PMFC), up flow membrane-less microbial fuel cell (up flow ML-MFC), Sediment microbial fuel cells (SMFCs)

\section{CONCLUSIONS}

This review summarized literature results and analytical deductions from reported, laboratory-scale MFC studies dealing with treatment of organics and nitrogen polluted wastewaters. Microbial Fuel Cells (MFCs) represent a still largely untapped technology for the recovery of energy and resources through wastewater treatment. Notwithstanding the technology's appeal, its practical application is still hampered by several drawbacks that ought to be overcome by a mix of new materials technologies and appropriate operating and control strategies, to accompany this technology to its final industrialization.MFCs represent a promising, novel, cost effective, environ-benign technology for sustainable energy production. This study suggests that not only microorganisms, algae can produce the electricity in same efficiently with the microbial fuel cells. The results also implies that the diversity of algae that have been produce 
electricity in MFCs with concomitant transfer of electrons to an MFC electrode. The power density output from MFCs might be improved by altering the design of MFC configuration or changing the physical/chemical environment.MFCs are based on using green fuels and on converting their latent chemical energy into electrical energy. Therefore, various substrates including hydrocarbons, volatile fatty acids, alcohols, amino acids, proteins, and even inorganic materials have been used in this system. Egesta and real waste such as wastewater have also been treated successfully and generated suitable amounts of energy in this system. Of course, wastewater contain materials that are of different levels of bio- degradability, and the higher the percentages of materials with high levels of biodegradability are, the greater quantities of electricity will be generated. Therefore, these systems can be used in treatment plants and in factories for treating the outgoing wastewater and for recovering part of the energy consumed by the units. This will reduce costs and, more importantly, will protect the environment. However, more applied research is needed to make this system operational and economically justifiable. Furthermore, for sustainable future growth and development in the economic world, MFCs are the best possible solution and an important field of research and innovation. 


\section{Reference}

Alaraj, M., Ren, Z. J., \& Park, J.D. (2014). Microbial fuel cell energy harvesting using synchronous flyback converter. Journal of Power Sources, 247, 636-642.

Angioni, S., L. Millia, P. Mustarelli, E. Doria, M.E. Temporiti, B. Mannucci, F. Corana, E. Quartarone, Photosynthetic microbial fuel cell with polybenzimidazole membrane: synergy between bacteria and algae for wastewater removal and biorefinery, Heliyon, 2018, 4, (3), e00560, https://doi.org/10.1016/j.heliyon.2018.e00560.

Ayyaru S and Dharmalingam S. Development of MFC using sulphonated polyether ether ketone (SPEEK) membrane for electricity generation from wastewater. Bioresour Techol. 2011;102:11167-11171.

Bakhshian S, Kariminia HR, Roshandel R. Bioelectricity generation enhancement in a dual chamber microbial fuel cell under cathodic enzyme catalyzed dye decolorization. Bioresour Technol. 2011;102:6761-6765

Behera, M., Ghangrekar, M.M. 2009. Performance of microbial fuel cell in response to change in sludge loading rate at different anodic feed $\mathrm{pH}$. Bioresour Technol, 100(21), 5114-5121.

Cercado-Quezada, B., Délia, M.L., Bergel, A., 2010. Testing various food-industry wastes for electricity production in microbial fuel cell. Bioresour. Technol. 101, $2748-2754$. 
Chen, J.-Y., L. Zhao, N. Li, H. Liu A microbial fuel cell with the three-dimensional electrode applied an external voltage for synthesis of hydrogen peroxide from organic matter J. Power Sources, 287 (2015), pp. 291-296.

Chen, X., P. Liang, X. Zhang, X. Huang, Bioelectrochemical systems-driven directional ion transport enables low-energy water desalination, pollutant removal, and resource recovery, Bioresour. Technol. 215 (2016) 274-284.

Chouler, J.; Di Lorenzo, M. Water quality monitoring in developing countries; can microbial fuel cells be the answer? Biosensors 2015, 5, 450-470.

Corbella, C., Guivernau, M., Vinas, M., \& Puigagut, J. (2015). Operational, design and microbial aspects related to power production with microbial fuel cells implemented in constructed wetlands. Water Research, 84, 232-242.

Cui D, Guo YQ, Lee HS, Wu WM, Liang B, Wang AJ, Cheng HY (2014) Enhanced decolorization of azo dye in a small pilot-scale anaerobic baffled reactor coupled with biocatalyzed electrolysis system (ABR-BES): a design suitable for scalingup. Bioresour Technol 163:254-261.

El Mekawy, A., H.M. Hegab, D. Pant, The near-future integration of microbial desalination cells with reverse osmosis technology, Energ. Environ. Sci. 7 (2014) 3921-3933.

Fangzhou D, Zhenglong L, Shaoqiang Y, et al. Electricity generation directly using human feces wastewater for life support system. Acta Astronaut. 2011;68:15371547

Fernando E, Keshavarz T, Kyazze G. Enhanced bio decolourisation of acid orange 7 by Shewanella oneidensis through co-metabolism in a microbial fuel cell. Int Biodeter Biodegr. 2012;72:1-9.

Ha PT, Lee TK, Rittmann BE, Park J, Chang IS. Treatment of alcohol distillery wastewater using a bacteroidetes dominant thermophilic microbial fuel cell. Environ Sci Technol. 2012;46:3022-3030.

Hai-ming Jiang, Combination of Microbial Fuel Cells with Microalgae Cultivation for Bioelectricity Generation and Domestic Wastewater Treatment. Environmental Engineering Science. 2017 Vol. 34, No. 7 https://doi.org/10.1089/ees.2016.0279 
Haiping Luo, Guofang Xu, Yaobin Lu, Guangli LiuORCID logo*, Renduo Zhang, Xiao Li, Xiyuan Zheng and Meihan Yu. Electricity generation in a microbial fuel cell using yogurt wastewater under alkaline conditions. 2017, 7, 32826-32832

Hamelers, H.V.M., Ter Heijne, A., Sleutels, T.H.J.A., Jeremiasse, A.W., Strik, D.P.B.T.B., Buisman, C.J.N. 2010. New applications and performance of bioelectrochemical systems. Appl Microbiol Biotechnol, 85(6), 1673-1685.

Hou B, Sun J, Hu YY (2011) Simultaneous Congo red decolorization and electricity generation in air-cathode single-chamber microbial fuel cell with different microfiltration, ultrafiltration and pro-ton exchange membranes. Bioresour Technol 102:4433-4438.

Jayashree, C. K. Tamilarasan, M. Rajkumar, P. Arulazhagan, K.N. Yogalakshmi, M. Srikanth, J. Rajesh Banu, Treatment of seafood processing wastewater using upflow microbial fuel cell for power generation and identification of bacterial community in anodic biofilm, Journal of Environmental Management,180, (2016), $351-358$

Jiang, H., Luo, S., Shi, X. Meng Dai. Rong-bo Guo. A system combining microbial fuel cell with photobioreactor for continuous domestic wastewater treatment and bioelectricity generation. J. Cent. South Univ. (2013) 20: 488. https://doi.org/10.1007/s11771-013-1510-2

Jiang, Y.; Liang, P.; Liu, P.; Wang, D.; Miao, B.; Huang, X. A novel microbial fuel cell sensor with biocathode sensing element. Biosens. Bioelectron. 2017, 94, 344-350.

Kan J, Hsu L, Cheung ACM, Pirbazari M, Nealson KH. (2011). Current production by bacterial communities in microbial fuel cells enriched from wastewater sludge with different electron donors. Environ Sci Technol 45: 1139-1146.

Kiely PD, Cusick R, Call DF, Selembo PA, Regan JM, Logan BE. (2011a). Anode microbial communities produced by changing from microbial fuel cell to microbial electrolysis cell operation using two different wastewaters. Bioresource Technol 102: 388-394.

Li XM, Cheng KY, Selvam A, et al. Bioelectricity production from acidic food waste leachate using microbial fuel cells: effect of microbial inocula. Process Biochem. 2013;48:283-288 
Lian J., Tian X., Li Z., Guo J., Guo Y., Yue L., et al. (2017). The effects of different electron donors and electron acceptors on perchlorate reduction and bioelectricity generation in a microbial fuel cell. Int. J. Hydrogen Energy 42, 544-552.

Logan, B. E. (2008). Microbial Fuel Cells, Wiley-Interscience. 216p .

Logan, B. E. (2012). Essential data and techniques for conducting microbial fuel cell and other types of bioelectrochemical system experiments. ChemSusChem, 5, 988994.

Logan, B. E., Hamelers, B., Rozendal, R., Schröder, U., Keller, J., Freguia, S., Rabaey, K. (2006). Microbial Fuel Cells: Methodology and Technology. Environmental Science \& Technology, 40, 5181-5192.

Logan, B.E. and K. Rabaey., Conversion of wastes into bioelectricity and chemicals using microbial electrochemical technologies Science, 337 (6095) (2012), pp. 686-690

Logroño, W., Pérez, M., Urquizo, G., Kadier, A., Echeverría, M., Recalde, C., \& Rákhely, G. (2017). Single chamber microbial fuel cell (SCMFC) with a cathodic microalgal biofilm: A preliminary assessment of the generation of bioelectricity and biodegradation of real dye textile wastewater. Chemosphere, 176, 378-388. DOI: 10.1016/j.chemosphere.2017.02.099

Malvankar, N.S. and Lovley, D.R. (2012). Microbial Nanowires: A New Paradigm for Biological Electron Transfer and Bioelectronics. ChemSusChem, 5(6), 10391046

Mateo-Sagasta J, Raschild-Sally L, Thebo A. Global Wastewater and Sludge Production, Treatment and Use. In: Drechsel P, Qadir M, Wichelns D, editors. Wastewater Econ. Asset an Urban. World, 2015, p. 1-282.

Mehanna, M.; Kiely, P. D.; Call, D. F.; Logan, B. E. A microbial electrodialysis cell for simultaneous water desalination and hydrogen gas production. Environ. Sci. Technol. 2010, 44, 9578-9583

Monzon O, Yang Y, Kim J, Amy Heldenbrand, Qilin Li, Pedro J.J. Alvarez. Microbial fuel cell fed by Barnett Shale produced water: power production by hypersaline autochthonous bacteria and coupling to a desalination unit. Biochem Eng J. 2017;117:87-91. 
Neethu and M. M. Ghangrekar. Electricity generation through a photo sediment microbial fuel cell using algae at the cathode 2017, wst2017485; DOI: 10.2166/wst.2017.48 5

Patil, S.A., Surakasi, V.P., Koul, S., Ijmulwar, S., Vivek, A., Shouche, Y.S., Kapadnis, B.P., 2009. Electricity generation using chocolate industry wastewater and its treatment in activated sludge based microbial fuel cell and analysis of developed microbial community in the anode chamber. Bioresour. Technol.100 (21), 51325139.

Penteado ED., Fernandez-Marchante CM, Zaiat M, et al. Influence of sludge age on the performance of MFC treating winery wastewater. Chemospher. 2016;151:163170.

Ren, L.; Ahn, Y.; Logan, B. E. A two-stage microbial fuel cell and anaerobic fluidized bed membrane bioreactor (MFC-AFMBR) system for effective domestic wastewater treatment. Environ. Sci. Technol. 2014, 48, 4199-4206.

Rengasamy, K., Berchmans, S., 2012. Simultaneous degradation of bad wine and electricity generation with the aid of the coexisting biocatalysts Acetobacter aceti and Gluconobacter roseus. Bioresour. Technol. 104, 388-393.

Retnaningrum, Endah and Wahyu Wilopo Performance and bacterial composition of anodic biofilms in microbial fuel cell using dairy wastewater. AIP Conference Proceedings 1744, 020018 (2016); doi: 10.1063/1.4953492

Ronald Huarachi-Olivera, Alex Dueñas-Gonza, Ursulo Yapo-Pari, Patricia Vega, Margiht Romero-Ugarte, Juan Tapia, Luis Molina, Antonio Lazarte-Rivera, D.G. PachecoSalazar, Mario Esparza, Bioelectrogenesis with microbial fuel cells (MFCs) using the microalga Chlorella vulgaris and bacterial communities, Electronic Journal of Biotechnology, 2018,31, 34-43.

Samsudeen, N., T.K. Radhakrishnan, M. Matheswaran Bioelectricity production from microbial fuel cell using mixed bacterial culture isolated from distillery wastewater Bioresour. Technol., 195 (2015), pp. 242-247

Sanchez, D., Jacobs, D., Gregory, K., Huang, J., Hu, Y., Vidic, R., \& Yun, M. (2015). Changes in Carbon Electrode Morphology Affect Microbial Fuel Cell Performance with Shewanella oneidensis MR-1. Energies, 8, 1817-1829. 
Santoro C, Ieropoulos I, Greenman J, et al. Power generation and contaminant removal in single chamber microbial fuel cells (SCMFCs) treating human urine. Int J Hydrog Energy. 2013;38:11543-11551

Santoro, C., Lei, Y., Cristiani, P., U., Li, B. (2012).Power generation from wastewater using single chamber microbial fuel cells (MFCs) with platinum-free cathodes and pre-colonized anodes. Biochemical Engineering Journal, 62: 8-16.

Sevda, S., H. Yuan, Z. He, I. M. Abu-Reesh, Microbial desalination cells as a versatile technology: functions, optimization and prospective, Desalination 371 (2015) 917

Sharma, Y., Parnas, R., and Li, B (2011). Bioenergy production from glycerol in hydrogen producing bioreactors (HPBs) and microbial fuel cells (MFCs). International Journal Hydrogen Energy, 36(6): 3853- 3861

Thung WE, Ong SA, Ho LN, Wong YS, Ridwan F, Oon YL, Oon YS, Lehl HK (2015) A highly efficient single chambered up-flow membrane-less microbial fuel cell for treatment of azo dye Acid Orange 7-containing wastewater. Bioresour Technol 197:284-288.

Tremouli A, Antonopoulou G, Bebelis S, et al. Operation and characterization of a microbial fuel cell fed with pretreated cheese whey at different organic loads. Bioresour Technol. 2013;131:380-389.

Velasquez-Orta, S.B., Head, I.M., Curtis, T.P., Scott, K., 2011. Factors affecting current production in microbial fuel cells using different industrial wastewaters. Bioresour. Technol. 102 (8), 5105-5112.

Yadav, A. K. S. K. Nayak, B. C. Acharya \& B. K. Mishra (2015) Algal-assisted Microbial Fuel Cell for Wastewater Treatment and Bioelectricity Generation, Energy Sources, Part A: Recovery, Utilization, and Environmental Effects, 37:2, 127-133, DOI: 10.1080/15567036.2011.576422.

Yang, F., Ren, L., Pu, Y., \& Logan, B. E. (2013). Electricity generation from fermented primary sludge using single-chamber air-cathode microbial fuel cells. Bioresource Technology, 128, 784-787.

Zhang Y, Angelidaki I (2015) Recovery of ammonia and sulfate from waste streams and bioenergy production via bipolar bioelectrodialysis. Water Res 85:177-184 
Zhang, X.; He, W.; Ren, L.; Stager, J.; Evans, P. J.; Logan, B. E. COD removal characteristics in air-cathode microbial fuel cells. Bioresour. Technol. 2015, 176, 23-31.

Lee, D.J.; Chang, J.S.; Lai, J.Y. Microalgae-microbial fuel cell: A mini review. Bioresour. Technol. 2015, 198, 891-895.

Zhang, G.; Jiao, Y.; Lee, D.J. A lab-scale anoxic/oxic-bioelectrochemical reactor for leachate treatments. Bioresour. Technol. 2015, 186, 97-105.

Sharma, V.; Kundu, P.P. Biocatalysts in microbial fuel cells. Enzyme Microb. Technol. 2010, 47, 179-188. 